\title{
Manajemen Laba pada Periode Initial Public Offering dan Dampaknya pada Persistensi Laba
}

\author{
Hansen Halim ${ }^{1}$ \\ Fakultas Ekonomi dan Bisnis \\ Universitas Katolik Indonesia Atma \\ Jaya, Indonesia
}

\author{
Stevanus Pangestu ${ }^{2}$ \\ Fakultas Ekonomi dan Bisnis \\ Universitas Katolik Indonesia Atma \\ Jaya, Indonesia
}

\begin{abstract}
Surel : pangestu@atmajaya.ac.id
\section{ABSTRAK}

Tujuan penelitian ini adalah menguji apakah perusahaan yang melakukan initial public offering (IPO) di Indonesia menggunakan manajemen laba melalui aktivitas riil dan akuntansi akrual pada saat tahun IPO untuk memanipulasi laba. Penelitian ini juga menganalisis pengaruh dari manajemen laba terhadap persistensi laba pada peristensi laba pada periode berikutnya. Penelitian ini menggunakan sampel dari 73 perusahaan non-finansial yang melakukan IPO pada periode 2014-2017. Penelitian ini menemukan bahwa perusahaan IPO di Indonesia melakukan manajemen laba riil dan akrual selama periode IPO untuk meningkatkan laba. Penelitian ini juga menemukan bahwa manajemen laba akrual berpengaruh negatif signifikan terhadap persistensi laba, sedangkan manajemen laba riil berpengaruh positif signifikan terhadap persistensi laba.
\end{abstract}

Kata Kunci: IPO; Manajemen Laba; Persistensi Laba; Go Public;

\section{Earnings Management in Initial Public Offerings and Its Effect on Earnings Persistence}

\section{ABSTRACT}

The paper examinse whether Indonesian corporations manage their earnings through real activities and accrual accounting during their initial public offerings. We also investigate the effect of this IPO earnings management on earnings persistence in the subsequent period. Seventythree non-financial IPOs during 2014-2017 were taken as research sample. Afer a series of statistical analyses, we find that companies that went public committed both real and accrual earnings management to inflate income figures in their IPO year. Furthermore, we also find that accrual earnings management negatively affects earning persistence, whereas real earnings management positively affects earnings persistence.

Keywords: IPO; Earnings Management; Earnings Persistence, Go Public.

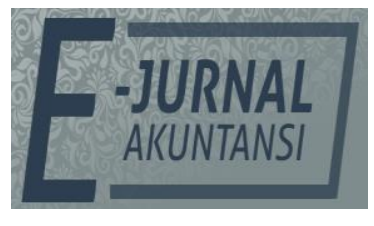

e-ISSN 2302-8556

Vol. 30 No. 11

Denpasar, Nopember 2020

Hal. 2922-2940

DOI:

10.24843/EJA.2020.v30.i11.p16

PENGUTIPAN:

Halim, H. \& Pangestu, S. (2020). Manajemen Laba pada Periode Initial Public Offering dan Dampaknya pada Persistensi Laba. EJurnal Akuntansi, 30(11), 2922-2940

RIWAYAT ARTIKEL:

Artikel Masuk: 4 Juli 2020

Artikel Diterima: 10 November 2020

Artikel dapat diakses : https://ojs.unud.ac.id/index.php/Akuntansi/index 


\section{PENDAHULUAN}

Pasar saham Indonesia sedang mengalami perkembangan yang sangat pesat. Bursa Efek Indonesia (BEI) menempatkan diri pada posisi ke-10 bursa saham yang paling banyak melakukan penawaran saham pertama atau Initial Public Offering (IPO) di tahun 2018 dengan jumlah 55 perusahaan atau 4\% dari seluruh IPO di dunia (Ernst and Young, 2019). IPO adalah aktivitas perusahaan untuk mendapatkan pendanaan dengan cara mengubah status perusahaan dari perusahaan tertutup menjadi perusahaan terbuka melalui penawaran saham kepada publik (go public) dan mencatatkan sahamnya bursa efek. Diharapkan ke depan semakin banyak lagi perusahaan yang melakukan IPO karena perusahaan melakukan IPO secara musiman saat pasar saham sedang panas (Brau \& Fawcett, 2006).

Perusahaan memiliki beberapa alasan untuk melakukan IPO, salah satunya adalah sebagai sarana pendanaan jangka panjang. Pendanaan yang didapat perusahaan dengan melakukan IPO dapat memperkuat struktur permodalan yang dimiliki perusahaan. IPO juga terutama dimotivasi oleh tujuan untuk melakukan akuisisi dan meningkatkan reputasi (Brau \& Fawcett, 2006).

Perusahaan akan cenderung memiliki kinerja buruk setelah melakukan IPO karena perusahaan akan memilih untuk go public ketika puncak dari perkembangan industrinya sudah hampir berakhir (Ritter, 1991). Kinerja perusahaan yang menurun akan dapat berpengaruh negative terhadap pergerakan harga saham. Pemegang saham terdahulu dapat mengambil keuntungan dengan melakukan transfer kepemilikan kepada investor baru yang memiliki informasi yang lebih sedikit mengenai perusahaan (Ertimur et al., 2018). Transfer kepemilikan tersebut dilakukan dengan menjual saham pada saat lock-up period berakhir sehingga pemegang saham sebelum IPO akan menerima transfer kekayaan dari investor baru sebelum harga saham semakin menurun.

Setelah lock-up period berakhir, volume perdagangan saham akan meningkat rata-rata secara permanen sekitar 40\% menunjukkan adanya pengurangan kepemilikan secara signifikan yang dilakukan oleh pemegang saham terdahulu (Field \& Hanka, 2001). Keuntungan yang diterima oleh pemegang saham terdahulu bergantung kepada harga pasar saham di sekitar berakhirnya lock-up period. pemegang saham terdahulu akan mempengaruhi manajemen untuk melaporkan laba yang lebih tinggi pada periode IPO dengan harapan untuk meningkatkan keuntungan dari transfer kepemilikan tersebut ((Ertimur et al., 2014) dan (Kedia et al., 2017)

Graham et al., (2005) mengemukakan bahwa manajer perusahaan cenderung memilih untuk mengorbankan nilai perusahaan untuk melakukan manajemen laba agar dapat melaporkan laba yang lebih tinggi. Penelitian sebelumnya telah dilakukan untuk mengetahui apakah terjadi manajemen laba di sekitar periode IPO dan menemukan bahwa tidak adanya manajemen laba yang signifikan sebelum periode IPO dan manajemen cenderung konservatif dalam menyajikan laporan keuangan pada prospektus. (Ball \& Shivakumar, 2008), (Premti, 2013), (Teoh et al., 1998) dan (Widyaningtyas, 2009). Penelitian terdahulu juga menunjukkan bahwa manajemen laba lebih signifikan dilakukan pada periode IPO karena manajemen memiliki insentif untuk mempertahankan harga saham selama lock-up period dan untuk menghindari risiko litigasi jika terjadi 
penurunan laba dan harga saham yang signifikan pada periode IPO (Alhadab et al., 2015), (Premti, 2013), dan (Teoh et al., 1998).

Perusahaan dapat melakukan manajemen laba dalam dua bentuk yaitu manajemen laba akrual dan manajemen laba riil (Roychowdhury, 2006). Manajemen laba akrual dilakukan dengan memilih kebijakan akuntansi terhadap akrual sesuai dengan diskresi manajemen yang bersifat subjektif dalam rangka menurunkan dan menaikkan laba (Scott, 2015). Sedangkan manajemen laba riil dilakukan dengan melakukan manipulasi terhadap praktik operasi normal untuk memberikan informasi yang menyesatkan kepada stakeholder bahwa tujuan perusahaan dari operasi perusahaan telah tercapai (Roychowdhury, 2006).

Teori Keagenan (Jensen \& Meckling, 1976) menyatakan bahwa hubungan keagenan timbul karena adanya kontrak dari principal yang memperkerjakan agent untuk melakukan jasa atas untuk kepentingan principal dengan mendelegasikan wewenang kepada agent untuk membuat keputusan yang terbaik bagi principal. Pada kenyataannya, kedua belah pihak principal dan agent merupakan utility maximizer atau selalu mementingkan dirinya sendiri sehingga akan tibul konflik kepentingan antara principal dan agent yang disebut dengan agency problem. perusahaan yang telah melakukan IPO akan memiliki pemisahan yang semakin signifikan antar principal yang merupakan pemegang saham dan agent yang merupakan manajemen perusahaan sehingga agency problem akan meningkat setelah perusahaan go public. Ball \& Shivakumar (2008) melakukan penelitian mengenai kualitas laba yang disajikan pada periode sebelum IPO. Penelitian ini dilakukan terhadap 393 perusahaan Inggris yang melakukan IPO pada tahun 1992-1999. Penelitian ini mengukur manajemen laba akrual menggunakan proksi asymmetric accrual menggunakan model Jones yang dimodifikasi dengan data yang didapat dari prospektus. Penelitian ini membuktikan bahwa perusahaan di Inggris cenderung lebih konservatif dalam menyajikan prospektus. Tidak ditemukan manajemen laba akrual pada periode sebelum IPO yang signifikan yang bertujuan untuk meningkatkan laba seperti pandangan pada umumnya.

Premti (2013) melakukan penelitian terhadap manajemen laba sebelum periode IPO dan pada periode IPO terhadap 4962 sampel perusahaan yang berasal dari 28 negara yang berbeda. Penelitian ini hanya mengukur manajemen laba menggunakan discretionary accrual saja. Hasilnya menunjukkan manajemen laba untuk meningkatkan laba lebih signifikan dilakukan pada periode IPO. 25 dari 28 negara menunjukkan hasil discretionary accrual pada periode IPO yang lebih tinggi daripada periode sebelum IPO.

Meini \& Siregar (2014) melakukan penelitian untuk mengetahui pengaruh manajemen laba terhadap persistensi laba pada 155 sampel perusahaan yang terdaftar di BEI pada tahun 2001-2014. Penelitian ini mengukur manajemen laba riil dengan menggunakan proksi abnormal cash flow from operation (CFO), abnormal production dan abnormal discretionary expenses sedangkan manajemen laba akrual dilakukan dengan discretionary accrual. Penelitian tersebut menyatakan bahwa manajemen laba yang dilakukan oleh perusahaan di Indonesia tidak berdampak terhadap persistensi laba dan dianggap merupakan bentuk dari efficient contracting. 
Alhadab et al. (2015) melakukan penelitian mengenai pengaruh manajemen laba riil dan akrual berpengaruh terhadap risiko kegagalan IPO. Penelitian tersebut dilakukan terhadap 570 perusahaan Inggris yang melakukan IPO pada tahun 1998-2008. Penelitian tersebut mengukur manajemen laba riil dan akrual pada periode IPO, setahun sebelum IPO, dan dua tahun sebelum IPO. Manajemen laba riil diukur dengan proksi abnormal CFO dan abnormal discretionary expenses sedangkan manajemen laba akrual menggunakan proksi discretionary accruals. Penelitian tersebut menujukan bahwa pada periode IPO perusahaan melakukan manajemen laba riil dan akrual secara signifikan namun manajemen laba menggunakan pengurangan discretionary expenses tidak ditemukan. Sesuai dengan penelitian sebelumnya oleh Ball dan Shivakumar (2008), hasil penelitian tersebut menunjukkan bahwa perusahaan tidak melakukan manajemen laba pada periode sebelum IPO.

Alhadab (2018) kembali melakukan penelitian untuk mengetahui manajemen laba yang dilakukan oleh perusahaan pada periode sekitar IPO. Penelitian ini berbeda dengan penelitian sebelumnya yang menggunakan perusahaan di negara maju seperti Amerika dan Inggris sebagai objek penelitiannya. Penelitian ini dilakukan terhadap perusahaan di negara berkembang yaitu Yordania dengan menggunakan 41 sampel perusahaan yang melakukan IPO pada tahun 2000-2011. Sejalan dengan penelitian yang Ia lakukan sebelumnya, hasil menunjukkan bahwa perusahaan di Yordania melakukan manajemen laba riil dan akrual dengan signifikan untuk meningkatkan laba pada periode IPO. Hasil tersebut menyimpulkan bahwa manajemen laba pada periode IPO terjadi pada negara berkembang maupun negara maju.

$\mathrm{Li}$ (2019) melakukan penelitian terhadap pengaruh manajemen laba riil terhadap persistensi laba. Li melakukan penelitian terhadap sampel dari perusahaan Amerika pada tahun 1975-2016. Li mengukur manajemen laba riil hanya dengan menggunakan proksi pengurangan abnormal discretionary expense. Penelitian tersebut menemukan bahwa manajemen laba dengan menggunakan pengurangan abnormal discretionary expense berpengaruh signifikan terhadap penurunan persistensi laba. Selain itu Li juga menemukan bahwa kerugian yang dialami oleh perusahaan akan berpengaruh signifikan terhadap penurunan laba.

Rajizadeh dan Rajizadeh (2013) melakukan penelitian mengenai pengaruh ukuran perusahaan dan leverage terhadap persistensi laba. Penelitian tersebut menemukan bahwa ukuran perusahaan berpengaruh signifikan terhadap persistensi laba dan perusahaan yang memiliki rasio debt to equity lebih kecil memiliki persistensi laba yang lebih tinggi dibandingkan perusahaan yang memiliki rasio debt to equity yang lebih tinggi.

Ertimur et al. (2018) berpendapat bahwa pemegang saham terdahulu dapat mengambil keuntungan dari proses IPO dengan melakukan transfer kepemilikan kepada investor baru. Transfer kepemilikan tersebut dapat dilakukan setelah lockup period berakhir. Besarnya keuntungan tersebut didasarkan harga saham pada lock-up period berakhir. Faktor yang paling mendorong minat investor terhadap perusahaan IPO adalah informasi mengenai laba (Brau \& Fawcett, 2006). Oleh karena itu, manajemen memiliki insentif yang kuat untuk menyajikan laba yang tinggi di sekitar periode IPO untuk meningkatkan harga saham di sekitar akhir lock-up period. 
Walaupun manajemen laba riil telah cukup lama dikenal, pengetahuan mengenai bagaimana manajemen laba riil dapat berpengaruh terhadap kualitas laba masih minim karena penelitian yang telah dilakukan masih sangat sedikit dibandingkan dengan manajemen laba akrual (DeFond, 2010; Li, 2019). Manajemen laba memberikan konsekuensi yang buruk terhadap kinerja perusahaan di masa depan dan manajemen laba riil akan memberikan konsekuensi yang lebih buruk daripada manajemen laba akrual (Cohen \& Zarowin, 2010), (Graham et al., 2005), dan (Kothari et al., 2016). Persistensi laba dapat menunjukkan kinerja perusahaan dengan menunjukkan kelanjutan dan ketahanan laba pada saat ini terhadap laba masa depan (Atwood et al., 2010) dan (Lipe, 1990).

Meini \& Siregar (2014) melakukan penelitian terhadap perusahaan di Indonesia dan menemukan bahwa manajemen laba riil dan akrual tidak berpengaruh terhadap persistensi laba. Ia menyatakan bahwa hal tersebut dikarenakan adanya suatu bentuk efficient contracting. Berlawanan dengan hasil penelitian Li (2019) yang menemukan bahwa perusahaan yang melakukan manajemen laba riil memiliki persistensi laba yang signifikan lebih rendah.

Mempertimbangkan research gap tersebut dan banyaknya literatur yang menunjukkan perusahaan IPO melakukan praktik manajemen laba, dan minimnya penelitian mengenai dampak manajemen laba terhadap peristensi laba pada perusahaan yang melakukan IPO, penelitian ini bertujuan untuk menganalisis pengaruh manajemen laba riil dan akrual yang dilakukan oleh manajemen perusahaan dilakukannya IPO terhadap persistensi laba setahun setelah dilakukannya IPO. Penelitian ini akan membahas mengenai fenomena manajemen laba oleh perusahaan yang melakukan IPO di BEI pada tahun 20142017 dan mengamati persistensi laba pada tahun berikutnya.

Penelitian mengenai pengaruh manajemen laba riil dan akrual pada periode IPO terhadap persistensi laba belum banyak yang meneliti. Namun, terdapat beberapa penelitian sebelumnya mengenai manajemen laba riil dan akrual di sekitar periode IPO dan analisis dari dampaknya.

Langkah oportunis dapat diambil manajemen untuk menyajikan laba yang tinggi yaitu dengan melakukan manajemen laba. Manajemen cenderung menyajikan labanya secara konservatif sebelum periode IPO (Ball \& Shivakumar, 2008). Manajemen memiliki insentif untuk memanipulasi laba pada periode IPO untuk mempertahankan harga saham dan menghindari risiko litigasi ketika harga saham jatuh setelah dilakukan IPO (Teoh et al., 1998). Penelitian sebelumnya juga mendukung pernyataan tersebut dengan menemukan bahwa manajemen laba yang dilakukan pada periode IPO lebih signifikan daripada yang dilakukan sebelum IPO. Oleh karena itu dapat dirumuskan hipotesis sebagai berikut.

$\mathrm{H}_{1}$ : Perusahaan melakukan manajemen laba pada periode IPO untuk menyajikan laba yang lebih tinggi.

Menggunakan teori persinyalan, manajemen dapat melakukan manajemen laba untuk memberikan sinyal seolah-olah ada ekspektasi mengenai profitabilitas di masa depan yang tidak tercermin di dalam historical cost accounting (Subramanian \& Nilakanta, 1996). Menurut penelitian sebelumnya, mmanajemen laba riil dapat memberikan konsekuensi yang signifikan terhadap kinerja perusahaan dan dapat merugikan operasional perusahaan (Cohen \& Zarowin, 
2010; Kothari et al., 2016). Oleh karena itu dapat dirumuskan hipotesis bahwa manajemen laba riil pada periode IPO dapat memberikan pengaruh negatif terhadap persistensi laba.

$\mathrm{H}_{2}$ : Manajemen laba riil pada periode IPO berpengaruh negatif terhadap persistensi laba.

Konsep akrual dalam pelaporan keuangan memungkinkan perusahaan mencatat pendapatan dan beban tidak pada periode saat terjadinya transaksi. Perusahaan dapat melakukan manipulasi akrual dengan mencatat memasukkan pendapatan dari periode lain ke periode IPO atau menunda pencatatan beban pada periode IPO ke periode selanjutnya (Scott, 2015). Hal tersebut akan berdampak terhadap pendapatan dan beban pada periode selanjutnya. Oleh karena itu dapat dirumuskan hipotesis bahwa manajemen laba akrual akan berdampak negatif terhadap persistensi laba.

$\mathrm{H}_{3}$ : Manajemen laba akrual pada periode IPO berpengaruh negatif terhadap persistensi laba.

\section{METODE PENELITIAN}

Penelitian ini menggunakan tiga jenis variabel yaitu variabel dependen, variabel independen, dan variabel kontrol. Variabel dependen dalam penelitian ini adalah persistensi laba sedangkan variabel independennya adalah manajemen laba riil dan akrual. Penelitian juga menggunakan ukuran perusahaan, leverage, dan kerugian sebagai variabel kontrolnya.

Persistensi laba didefinisikan sebagai kontinuitas dan daya tahan dari laba pada saat ini. Laba yang lebih persisten disertai dengan kemampuan perusahaan untuk mempertahankan pendapatannya saat ini dan kualitas laba yang lebih tinggi (Lipe, 1990). Persistensi laba dapat diukur menggunakan model sebagai berikut (Dechow et al., 2010).

$E_{i, t+1}=\alpha_{0}+\beta_{1} E_{i, t}+\varepsilon_{i, t}$

Keterangan:

$E_{i, t+1}=$ laba pada periode setelahnya

$E_{i, t} \quad=$ laba selama periode

$\varepsilon_{i, t} \quad=$ Residual

Persistensi laba akan diukur dengan besarnya koefisien linear untuk model regresi di atas $\left(\beta_{1}\right)$. Semakin besar $\beta_{1}$ menunjukkan laba yang lebih persisten.

Penelitian ini menguji manajemen laba riil berdasarkan dua aktivitas yaitu manipulasi penjualan dan pengurangan discretionary expense. Manipulasi penjualan dapat dilakukan dalam bentuk memberikan lebih banyak potongan harga penjualan dan kebijakan kredit yang lebih luwes oleh karena itu peningkatan penjualan tidak akan sebanding dengan CFO (Alhadab et al., 2015). Model regresi yang dari CFO normal yang digunakan adalah sebagai berikut (Roychowdhury, 2006).

$\frac{\text { CFO }_{i, t}}{\operatorname{Assets}_{i, t-1}}=\alpha_{0}+\beta_{1} \frac{1}{\text { Assets }_{i, t-1}}+\beta_{2} \frac{\text { SALES }_{i, t}}{\operatorname{Assets}_{i, t-1}}+\beta_{3} \frac{\Delta \text { SALES }_{i, t}}{\operatorname{Assets}_{i, t-1}}+\varepsilon_{i, t}$

Keterangan:

$\mathrm{CFO}_{i, t} \quad=$ arus kas dari operasi selama periode

Assets $_{i, t-1}=$ total aset awal periode

$S_{A L E S}, \quad=$ penjualan selama periode 
$\begin{array}{ll}\triangle S A L E S_{i, t} & =\text { perubahan jumlah penjualan dari periode sebelumnya } \\ \varepsilon_{i, t} & =\text { residual }\end{array}$

Manipulasi penjualan akan ditunjukkan dengan perbedaan CFO aktual dan normal yang ditunjukkan oleh jumlah residual $\left(\varepsilon_{i, t}\right)$ dari persamaan tersebut. Residual yang bernilai negatif menunjukkan adanya manipulasi penjualan yang terjadi yang akan berdampak negatif terhadap CFO. Oleh karena itu manajemen laba riil melalui manipulasi penjualan diukur berdasarkan inversi dari residual model regresi tersebut.

Bentuk kedua dari manajemen laba riil dilakukan dengan mengurangi discretionary expense seperti beban pemasaran, beban riset dan pengembangan, dan beban iklan (Roychowdhury, 2006). Penelitian ini akan mengikuti model regresi discretionary expense normal yang telah dimodifikasi oleh Roychowdhury untuk mengatasi adanya manipulasi penjualan pada periode IPO sebagai berikut.

$\frac{\text { DISX }_{i, t}}{\text { Assets }_{i, t-1}}=\alpha_{0}+\beta_{1} \frac{1}{\text { Assets }_{i, t-1}}+\beta_{2} \frac{\text { SALES }_{i, t}}{\text { Assets }_{i, t-1}}+\varepsilon_{i, t}$

Keterangan:

$D I S X_{i, t}=$ discretionary expense selama periode (Advertisng Expense, $R \mathcal{E} D$ Expense dan SGEA Expense)

Assets $_{i, t-1}=$ total aset pada awal periode

SALES $_{i, t} \quad=$ penjualan selama periode

$\varepsilon_{i, t} \quad=$ residual

Pengurangan discretionary expense akan ditunjukkan oleh perbedaan discretionary expense normal dan aktual yang ditunjukkan oleh residual pada regresi di atas $\left(\varepsilon_{i, t}\right)$. Residual yang bernilai negatif menunjukkan adanya pengurangan discretionary expense yang dilakukan. Oleh karena itu manajemen laba riil melalui pengurangan discretionary expense diukur berdasarkan inversi dari residual model regresi tersebut. Nilai dari variabel independen manajemen laba riil akan dihitung dengan mengagregatkan kedua inversi residual kedua model regresi tersebut.

Manajemen laba akrual dalam penelitian ini diukur berdasarkan bersarnya discretionary accruals pada periode IPO. Untuk menghitung besarnya discretionary accruals, terlebih dahulu menghitung koefisien dari total akrual normal pada perusahaan yang tidak melakukan IPO sebagai populasi kontrol. Model regresi dari total akrual normal pada penelitian ini menggunakan model adaptasi crosssectional dari modified Jones model (Dechow et al., 1995). Penelitian ini juga memasukkan ROA ke dalam model untuk menghindari bias yang disebabkan oleh kinerja perusahaan. Total akrual normal diestimasi berdasarkan model berikut.

$\frac{T A_{i, t}}{\text { AvAssets }_{i, t}}=\alpha_{0}+\beta_{1} \frac{1}{\text { AvAssets }_{i, t}}+\beta_{2} \frac{\Delta \text { SALES }_{i, t}}{\text { AvAsset }_{i, t}}+\beta_{3} \frac{P P E_{i, t}}{\text { AvAssets }_{i, t}}+\beta_{4} R O A_{i, t}+\varepsilon_{i, t} \ldots \ldots .$.

Keterangan:

$T A_{i, t} \quad=$ total akrual (laba - arus kas dari operasi)

AvAssets $_{i, t} \quad=$ rata-rata total aset

$\triangle S A L E S_{i, t} \quad=$ perubahan penjualan dari periode sebelumnya

$P P E_{i, t} \quad=$ nilai aset tetap

$R_{0} A_{i, t} \quad=$ return on assets

$\varepsilon_{i, t} \quad=$ residual 
Koefisien yang didapat dari model regresi di atas kemudian digunakan untuk menghitung akrual normal $\left(N A_{i, t}\right)$ untuk perusahaan yang melakukan IPO dengan rumus sebagai berikut:

$$
N A_{i, t}=\alpha_{0}+\beta_{1} \frac{1}{\operatorname{AvAssets}_{i, t}}+\beta_{2} \frac{\Delta \operatorname{SALES}_{i, t}-\Delta R E C_{i, t}}{\operatorname{AvAsset}_{i, t}}+\beta_{3} \frac{P P E_{i, t}}{\operatorname{AvAssets}_{i, t}}+\beta_{4} R O A_{i, t} \ldots
$$

Keterangan:

$N A_{i, t} \quad=$ akrual normal

AvAssets $_{i, t} \quad=$ rata-rata total aset

$\triangle S A L E S_{i, t} \quad=$ perubahan penjualan dari periode sebelumnya

$\triangle R E C_{i, t} \quad=$ perubahan piutang dari periode sebelumnya

$P P E_{i, t} \quad=$ nilai aset tetap

$R O A_{i, t} \quad=$ return on assets

Discretionary accrual kemudian dihitung dengan mengurangi total akrual dengan akrual sebagai berikut:

$$
\mathrm{DA}_{\mathrm{i}, \mathrm{t}}=\left(\frac{\mathrm{TA}_{\mathrm{i}, \mathrm{t}}}{\text { AvAssets }_{\mathrm{i}, \mathrm{t}}}\right)-\mathrm{NA}_{\mathrm{i}, \mathrm{t}}
$$

Discrestonary accrual yang bernilai positif menunjukkan bahwa perusahaan melakukan manajemen laba dengan memanipulasi akrual pada periode IPO.

Ukuran perusahaan dalam penelitian ini akan diukur menggunakan logaritma natural dari total aset perusahaan pada akhir periode IPO. Persamaan yang digunakan untuk mengukur ukuran perusahaan adalah sebagai berikut.

$$
S I Z E_{i, t}=\ln \text { Assets }_{i, t}
$$

Keterangan:

$S I Z E_{i, t} \quad=$ ukuran perusahaan

Assets $_{i, t} \quad=$ total aset pada akhir periode

Leverage perusahaan dalam penelitian akan diukur menggunakan rasio debt to equity sebagai berikut.

$$
L E V_{i, t}=\frac{\text { Debt }_{i, t}}{\text { Equity }_{i, t}} .
$$

Keterangan:

$$
\begin{array}{ll}
L E V_{i, t} & =\text { rasio leverage } \\
\text { Debt }_{i, t} & =\text { total utang pada akhir periode } \\
\text { Equity }_{i, t} & =\text { total ekuitas pada akhir periode }
\end{array}
$$

Kerugian pada penelitian ini merupakan variabel dummy dimana perusahaan yang mengalami kerugian akan mendapat nilai 1 sedangkan yang tidak mengalami kerugian akan mendapat nilai 0 . Variabel kontrol tersebut digunakan agar model regresi yang digunakan juga dapat mengestimasi tingkat persistensi laba perusahaan yang mengalami kerugian karena perusahaan yang mengalami kerugian akan memiliki nilai persistensi yang negatif.

Uji statistik $t$ hipotesis sederhana digunakan untuk menguji hipotesis konseptual pertama perusahaan melakukan praktik manajemen laba riil dan akrual pada periode IPO. Hipotesis diuji dengan menguji apakah mean dan median dari proksi manajemen laba $>0$ pada periode IPO. Sedangkan untuk uji hipotesis kedua dan ketiga digunakan model model variasi cross-sectional dengan variabel interaksi (Li, 2019) untuk menguji pengaruh manajemen laba riil dan akrual terhadap persistensi laba. Model yang digunakan adalah sebagai berikut. 
$E_{i, t+1}=\alpha_{0}+\beta_{1} E_{i, t}+\beta_{2} R M_{i, t}+\beta_{3} R M_{i, t} * E_{i, t}+\beta_{3} A E M_{i, t}+\beta_{4} A E M_{i, t} * E_{i, t}+$

Cont $\Gamma_{i, t}+\varepsilon_{i, t}$

Keterangan:

$E_{i, t+1}=$ laba pada periode setelah IPO

$E_{i, t} \quad=$ laba pada periode IPO

$R M_{i, t} \quad=$ manajemen laba riil pada periode IPO

$\operatorname{Cont}_{i, t} \quad=$ seluruh variabel kontrol yang digunakan

$\varepsilon_{i, t} \quad=$ residual

\section{HASIL DAN PEMBAHASAN}

Objek penelitian yang pada penelitian ini adalah perusahaan yang melakukan IPO di BEI pada tahun 2014-2017. Objek penelitian yang dapat diobservasi adalah perusahaan yang melaporkan laporan keuangannya kepada BEI. Pada periode pengamatan tersebut, terdapat 94 perusahaan yang melakukan IPO. Dari populasi tersebut, penelitian ini hanya mengobservasi 73 perusahaan yang memiliki data yang sesuai dengan yang dibutuhkan penelitian ini dengan rincian sebagai berikut.

Tabel 1. Populasi Perusahaan yang Diobeservasi

\begin{tabular}{lc}
\hline \multicolumn{1}{c}{ Keterangan } & Jumlah Perusahaan \\
\hline Perusahaan yang melakukan IPO pada periode 2014-2017 & 94 \\
Perusahaan sektor keuangan & $(17)$ \\
Perusahaan yang tidak memiliki data yang dibutuhkan & $(2)$ \\
Perusahaan yang memiliki ekuitas negatif & $(1)$ \\
Perusahaan yang tidak dapat ditemukan laporannya & $(1)$ \\
Total perusahaan yang diobservasi & 73 \\
\hline
\end{tabular}

Sumber: Data Penelitian, 2019

Dari 94 perusahaan pada Tabel 1,17 perusahaan yang termasuk ke dalam industri keuangan tidak diikutsertakan ke dalam penelitian sehingga jumlah perusahaan yang termasuk ke dalam populasi adalah 77 perusahaan. Dari populasi penelitian tersebut, 2 perusahaan tidak memiliki data yang sesuai dengan yang dibutuhkan, 1 perusahaan memiliki angka ekuitas negatif, dan 1 perusahaan tidak dapat ditemukan laporan keuangannya sehingga total perusahaan yang diobservasi adalah sebanyak 73 perusahaan.

Tabel 2. Hasil Statistika Desksriptif

\begin{tabular}{|c|c|c|c|c|c|c|c|c|}
\hline & E1 & E0 & ABNCFO & $\begin{array}{c}\text { ABNDIS } \\
x\end{array}$ & REM & AEM & SIZE & LEV \\
\hline Mean & 0.061215 & 0.077522 & 0.304934 & 0.181060 & 0.485993 & 0.051586 & $2.26 \mathrm{E}+12$ & 0.808319 \\
\hline & 603 & 0.070300 & 0.013700 & 0.019500 & 0.010012 & 0.032500 & $1.36 \mathrm{E}$ & 0.554700 \\
\hline Maximum & 0.382700 & 0.624200 & 16.40560 & 9.096500 & 25.50214 & 0.714520 & $1.71 \mathrm{E}+$ & 3.839500 \\
\hline Minimum & $\begin{array}{c}- \\
0.141300\end{array}$ & & & 0.830200 & & & $5.08 \mathrm{E}$ & 0.011400 \\
\hline & 0.083420 & 0.098078 & 1.959934 & 1.142774 & 3.080758 & 0.169331 & $2.94 \mathrm{E}-$ & 0.752848 \\
\hline & 0. & 2. & 7.800 & 6.866463 & 7.7 & 1.139867 & 2.876 & 1.911124 \\
\hline Kurtosis & 5.668677 & 14.66089 & 64.21611 & 52.83289 & 62.72766 & 5.365385 & 13.00285 & 7.288332 \\
\hline Observation & 73 & 73 & 73 & 73 & 73 & 73 & 73 & 73 \\
\hline
\end{tabular}

Sumber: Data Penelitian, 2019 
Berdasarkan hasil analisis deskriptif pada Tabel 2, dapat dilihat bahwa laba pada periode satu tahun setelah IPO yang diskalakan dengan rata-rata total aset (E1) memiliki mean dan median yaitu 0,061215 dan 0,0603 menurun daripada periode sebelumnya saat IPO (E0) yaitu 0,077522 dan 0,0703 yang menandakan bahwa terjadi penurunan terhadap laba pada periode satu tahun setelah IPO dibandingkan dengan periode IPO.

Variabel manipulasi penjualan memiliki mean dan median bernilai positif yaitu sebesar 0,304934 dan 0,0137 menunjukkan bahwa perusahaan melakukan manajemen laba dengan memanipulasi penjualannya pada periode IPO yang berdampak negatif terhadap arus kas dari operasi. Jumlah perusahaan yang memiliki nilai ABNCFO positif adalah sebanyak 38 yang artinya 52,01\% perusahaan IPO melakukan manajemen laba riil melalui manipulasi penjualan.

Variabel pengurangan discretionary expense juga memiliki mean dan median yang positif yaitu sebesar 0,181060 dan 0,019500 yang berarti perusahaan juga mengurangi discretionary expense untuk meningkatkan laba pada periode IPO. Jumlah perusahaan yang memiliki nilai ABNDISX positif adalah sebanyak 49 yang artinya $67,12 \%$ perusahaan IPO melakukan manajemen laba riil melalui pengurangan discretionary expense.

Variabel manajemen laba riil merupakan agregat dari kedua jenis manajemen laba riil yaitu manipulasi penjualan (ABNCFO) dan Pengurangan discretionary expense (ABNDISX). Variabel REM memiliki mean dan median yang positif yaitu sebesar 0,485993 dan 0,010012 menunjukkan bahwa perusahaan melakukan manajemen laba dalam bentuk aktivitas riil pada periode IPO. Jumlah perusahaan yang memiliki nilai REM positif adalah sebanyak 37 yang artinya $50,69 \%$ perusahaan IPO melakukan manajemen laba riil.

Variabel manajemen laba akrual pada periode IPO juga memiliki mean dan median yang bernilai positif yaitu sebesar 0,051586 dan 0,032500 yang menunjukkan bahwa selain melakukan manajemen laba riil, perusahaan juga melakukan manajemen laba akrual. Jumlah perusahaan yang memiliki nilai AEM positif adalah sebanyak 45 yang artinya 61,64\% perusahaan IPO melakukan manajemen laba akrual.

\section{Tabel 3. Hasil Tabulasi Variabel REM dan AEM}

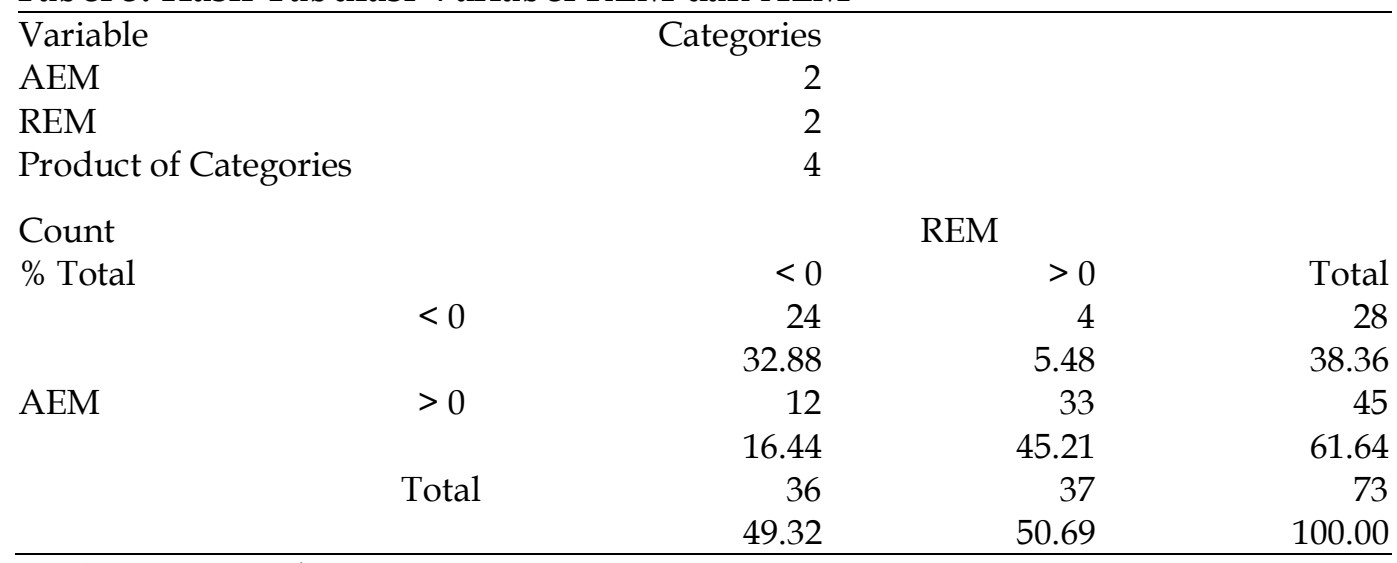

Sumber: Data Penelitian, 2019

Tabel 3, menunjukkan jumlah perusahaan yang melakukan manajemen laba riil dan akrual pada periode IPO. Manajemen laba riil dilakukan oleh 37 
perusahaan atau sebesar 50,69\% dari total sampel sedangkan manajemen laba akrual dilakukan oleh 45 perusahaan atau sebesar $61,64 \%$ dari total sampel dan terdapat 24 perusahaan yang tidak melakukan manajemen laba. Hal tersebut menunjukkan bahwa perusahaan lebih memilih untuk melakukan manajemen laba akrual daripada manajemen laba riil pada periode IPO. Dari total 37 perusahaan yang melakukan manajemen laba riil, 33 atau 89,19\% dari perusahaan tersebut juga melakukan manajemen laba akrual sedangkan dari total 45 perusahaan yang melakukan manajemen laba akrual, 33 atau 73,33\% dari perusahaan tersebut juga melakukan manajemen laba riil. Hal tersebut menunjukkan bahwa perusahaan yang melakukan manajemen laba riil lebih cenderung melakukan manajemen laba dalam bentuk lainnya daripada perusahaan yang melakukan manajemen laba akrual.

Selanjutnya untuk variabel kontrol leverage, diperoleh mean 0,808317 yang menunjukkan bahwa struktur pendanaan perusahaan yang melakukan IPO pada tahun 2014-2017 lebih banyak menggunakan pendanaan dari ekuitas. Variabel kontrol kerugian (LOSS) merupakan variabel dummy yang menunjukkan apakah perusahaan mengalami kerugian pada periode IPO. Perusahaan yang mengalami kerugian mendapatkan nilai 1 sedangkan yang tidak mengalami kerugian mendapatkan nilai 0 . Variabel kontrol tersebut digunakan agar model regresi yang digunakan juga dapat mengestimasi tingkat persistensi laba perusahaan yang mengalami kerugian karena perusahaan yang mengalami kerugian akan memiliki nilai persistensi yang negatif.

Tabel 4. Rangkuman Uji Hipotesis Sederhana

\begin{tabular}{lll}
\hline & Mean & Median \\
\hline $\begin{array}{l}\text { Manajemen laba riil } \\
\text { melalui manipulasi } \\
\text { penjualan (ABNCFO) }\end{array}$ & $0,126639^{* *}$ & $0,013664^{*}$ \\
$\begin{array}{l}\text { Manajemen laba riil } \\
\text { melalui pengurangan } \\
\text { discretionary expense } \\
\text { (ABNDISX) }\end{array}$ & $0,101949^{*}$ & $0,019474^{* * *}$ \\
$\begin{array}{l}\text { Agregat manajemen laba } \\
\text { riil (REM) }\end{array}$ & \\
$\begin{array}{l}\text { Manajemen laba akrual } \\
\text { (AEM) } \quad 0,049055^{* * *}\end{array}$ & $0,010012^{*}$ \\
$* \quad \quad$ Signifikan $>0$ pada level signifikansi 0,1 & $0,032500^{* * *}$ \\
$* \quad \quad$ Signifikan $>0$ pada level signifikansi 0,05 & \\
$* * * \quad$ Signifikan $>0$ pada level signifikansi 0,01 & \\
Sumber: Data Penelitian, 2019
\end{tabular}

Sumber: Data Penelitian, 2019

Pengujian seluruh hipotesis dalam penelitian ini telah melalui proses winsorization pada $2 \%$ dan $98 \%$ untuk mengeliminasi pengaruh dari outliers. Tabel 4, menunjukkan rangkuman dari hasil pengujian terhadap mean dan median dari variabel manajemen laba riil dan akrual pada periode IPO. Hasil pengujian tersebut menyatakan bahwa mean dan median secara signifikan lebih besar dari 0 atau bernilai positif, sehingga hipotesis pertama $\left(\mathrm{H}_{1}\right)$ terhadap mean dan median dari variabel manajemen laba pada periode IPO diterima sehingga menunjukkan bahwa perusahaan melakukan manajemen laba riil dan akrual pada periode IPO dengan tujuan untuk menyajikan laba yang lebih besar. 
Hal tersebut sejalan dengan signaling theory yaitu perusahaan memiliki insentif untuk mengirimkan sinyal positif untuk meningkatkan harga saham dengan menyajikan laba yang lebih besar dan sesuai dengan positive accounting theory bahwa perusahaan dapat bertindak oportunis dengan melakukan manajemen laba. Hasil penelitian ini konsisten dengan hasil penelitian yang dilakukan oleh Alhadab et al. (2015) dan Alhadab (2018) terhadap perusahaan yang melakukan IPO baik di negara maju maupun negara berkembang.

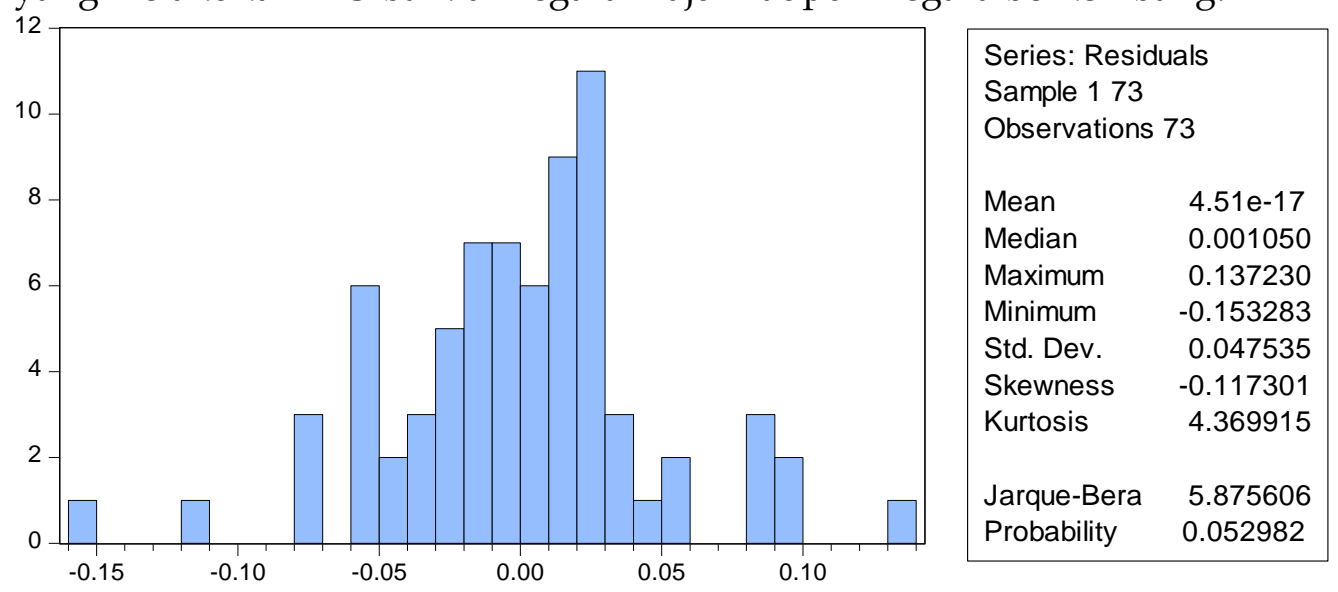

Gambar 1. Grafik Hasil Uji Normalitas

Sumber: Data Penelitian, 2019

Hasil uji normalitas pada Gambar 1, menunjukkan bahwa p-value JB lebih besar dari level signifikansi $0,05 \mathrm{H}_{0}$ tidak dapat ditolak. Dengan demikian dapat dikatakan bahwa residual dari model regresi tersebut terdistribusi dengan normal.

Tabel 5. Hasil Uji Heteroskedastisitas

\begin{tabular}{llll}
\hline F-statistic & 0.641703 & Prob. F(38,34) & 0.9076 \\
Obs*R-squared & 30.48887 & Prob. Chi-Square(38) & 0.8018 \\
Scaled explained SS & 39.48612 & Prob. Chi-Square(38) & 0.4034
\end{tabular}

Test Equation:

Dependent Variable: RESID ${ }^{\wedge} 2$

Method: Least Squares

Date: 12/17/19 Time: 20:43

Sample: 173

Included observations: 73

Collinear test regressors dropped from specification

$\begin{array}{llll}\text { R-squared } & 0.417656 & \text { Mean dependent var } & 0.002229 \\ \text { Adjusted R-squared } & -0.233200 & \text { S.D. dependent var } & 0.004119 \\ \text { S.E. of regression } & 0.004575 & \text { Akaike info criterion } & -7.632208 \\ \text { Sum squared resid } & 0.000712 & \text { Schwarz criterion } & -6.408538 \\ \text { Log likelihood } & 317.5756 & \text { Hannan-Quinn criter. } & -7.144554 \\ \text { F-statistic } & 0.641703 & \text { Durbin-Watson stat } & 1.868090\end{array}$

Prob(F-statistic) 0.907560

Sumber: Data Penelitian, 2019

Hasil uji heteroskedastisitas pada Tabel 5, menunjukkan bahwa p-value yang bernilai 0,8018 lebih besar dari level signifikansi 0,05 maka $\mathrm{H}_{0}$ tidak dapat 
ditolak. Oleh karena itu, dapat disimpulkan bahwa tidak terdapat heteroskedastisitas pada model regresi tersebut.

Tabel 6. Hasil Uji Autokorelasi

\begin{tabular}{lllll}
\hline Variable & Coefficient & Std. Error & t-Statistic & Prob. \\
\hline C & -0.054294 & 0.150646 & -0.360408 & 0.7197 \\
E0 & 0.781676 & 0.113927 & 6.861176 & 0.0000 \\
REM & $-4.51 E-05$ & 0.010127 & -0.004449 & 0.9965 \\
REM ${ }^{*}$ E0 & 0.828088 & 0.284123 & 2.914545 & 0.0049 \\
AEM & -0.036879 & 0.073851 & -0.499370 & 0.6192 \\
AEM ${ }^{*}$ E0 & -1.598552 & 0.719106 & -2.222972 & 0.0298 \\
SIZE & 0.002701 & 0.005522 & 0.489052 & 0.6265 \\
LEV & -0.016460 & 0.009184 & -1.792321 & 0.0778 \\
LOSS & -0.022124 & 0.022002 & -1.005575 & 0.3184 \\
R-squared & 0.627126 & Mean dependent var & 0.060855 \\
Adjusted R-squared & 0.580517 & S.D. dependent var & 0.077845 \\
S.E. of regression & 0.050418 & Akaike info criterion & -3.021934 \\
Sum squared resid & 0.162687 & Schwarz criterion & -2.739548 \\
Log likelihood & 119.3006 & Hannan-Quinn criter. & -2.909398 \\
F-statistic & 13.45497 & Durbin-Watson stat & 1.826402 \\
Prob(F-statistic) & 0.000000 & &
\end{tabular}

Sumber: Data Penelitian, 2019

Hasil uji autokorelasi pada Tabel 6, menunjukkan angka DW dari model regresi tersebut adalah 1,826. Pada level signifikansi 0,05 diketahui bahwa nilai batas bawah (dL) adalah 1,210 dan nilai batas atas (dU) adalah 1,756. Nilai DW terletak di daerah dU $<$ DW $<4$-dU yaitu 1,756 <1,826 < 2,244 maka dapat $\mathrm{H}_{0}$ tidak dapat ditolak dan dapat disimpulkan bahwa tidak terdapat masalah autokorelasi pada model regresi tersebut.

Tabel 7. Hasil Uji Multikolinearitas

\begin{tabular}{llll}
\hline Variable & $\begin{array}{l}\text { Coefficient } \\
\text { Variance }\end{array}$ & $\begin{array}{l}\text { Uncentered } \\
\text { VIF }\end{array}$ & $\begin{array}{l}\text { Centered } \\
\text { VIF }\end{array}$ \\
\hline C & 0.022694 & 651.7254 & NA \\
E0 & 0.012979 & 4.006095 & 1.982522 \\
REM & 0.000103 & 3.730093 & 3.576198 \\
REM $^{*}$ E0 & 0.080726 & 3.867263 & 3.833934 \\
AEM & 0.005454 & 4.043721 & 3.666826 \\
AEM ${ }^{*}$ E0 & 0.517113 & 3.056482 & 3.009141 \\
SIZE & $3.05 \mathrm{E}-05$ & 677.5605 & 1.224546 \\
LEV & $8.43 \mathrm{E}-05$ & 2.859059 & 1.292845 \\
LOSS & 0.000484 & 1.713897 & 1.502595 \\
\hline
\end{tabular}

Sumber: Data Penelitian, 2019 
Hasil uji multikolinieritas pada Tabel 7, menunjukkan bahwa variabel independen dan variabel kontrol pada model regresi tersebut memiliki nilai VIF $\leq$ 10 maka $\mathrm{H}_{0}$ tidak dapat ditolak. Dari hasil pengujian tersebut dapat disimpulkan pada model regresi penelitian ini tidak terdapat masalah multikolinearitas.

Tabel 8. Hasil Multiple Linear Regression

\begin{tabular}{lclcc}
\hline Variable & Coefficient & Std. Error & t-Statistic & Prob. \\
\hline C & -0.054294 & 0.150646 & -0.360408 & 0.7197 \\
E0 & 0.781676 & 0.113927 & 6.861176 & $0.0000^{* * *}$ \\
REM & $-4.51 E-05$ & 0.010127 & -0.004449 & 0.9965 \\
REM*E0 & 0.828088 & 0.284123 & 2.914545 & $0.0049^{* * *}$ \\
AEM & -0.036879 & 0.073851 & -0.499370 & 0.6192 \\
AEM*E0 & -1.598552 & 0.719106 & -2.222972 & $0.0298^{* *}$ \\
SIZE & 0.002701 & 0.005522 & 0.489052 & 0.6265 \\
LEV & -0.016460 & 0.009184 & -1.792321 & $0.0778^{*}$ \\
LOSS & -0.022124 & 0.022002 & -1.005575 & 0.3184 \\
R-squared & 0.627126 & Mean dependent var & 0.060855 \\
Adjusted R-squared & 0.580517 & S.D. dependent var & 0.077845 \\
S.E. of regression & 0.050418 & Akaike info criterion & -3.021934 \\
Sum squared resid & 0.162687 & Schwarz criterion & -2.739548 \\
Log likelihood & 119.3006 & Hannan-Quinn criter. & -2.909398 \\
F-statistic & 13.45497 & Durbin-Watson stat & 1.826402
\end{tabular}

Prob(F-statistic) 0.000000

Sumber: Data Penelitian, 2019

Koefisien variabel interaksi REM*E0 pada Tabel 8, memiliki koefisien yang bernilai positif $(0,828088)$ dan memiliki nilai $p$-value 0,0049 sehingga signifikan pada level signifikansi 0,01. Hasil dari pengujian hipotesis kedua $\left(\mathrm{H}_{2}\right)$ yaitu manajemen laba riil pada periode IPO berpengaruh signifikan negatif terhadap persistensi laba ditolak karena dari hasil pengujian menunjukkan sebaliknya yaitu berpengaruh signifikan positif terhadap persistensi laba.

Hal tersebut dikarenakan dampak negatif dari manajemen laba riil tidak langsung terlihat hanya dalam satu tahun atau terdapat keterbatasan model regresi untuk mengestimasi tingkat manajemen laba riil. Hasil tersebut sejalan dengan hasil penelitian oleh Meini \& Siregar (2014) namun bertentangan dengan pendapat yang menyatakan bahwa manajemen laba riil akan memiliki konsekuensi yang lebih buruk terhadap kinerja perusahaan daripada manajemen laba akrual (Graham et al., 2005).

Koefisien variabel interaksi AEM*E0 pada Tabel 8, memiliki koefisien yang bernilai negatif $(-1,598552)$ memiliki nilai p-value 0,0298 atau signifikan pada level signifikansi 0,05. Hasil dari pengujian hipotesis ketiga $\left(\mathrm{H}_{3}\right)$ diterima dan dapat disimpulkan bahwa manajemen laba akrual pada periode IPO secara signifikan berpengaruh negatif terhadap persistensi laba. Dapat disimpulkan bahwa manajemen laba pada periode IPO akan mengurangi kemampuan perusahaan untuk mempertahankan tingkat laba pada periode berikutnya. Hal tersebut 
bertentangan dengan hasil penelitian Meini \& Siregar (2014) bahwa manajemen laba akrual tidak berdampak negatif terhadap persistensi laba.

\section{SIMPULAN}

Hasil dari analisis data perusahaan yang melakukan IPO pada tahun 2014-2017 menunjukkan bahwa perusahaan melakukan manajemen laba baik dalam bentuk aktivitas riil maupun manipulasi akrual. Manajemen laba dilakukan perusahaan untuk menyajikan laba yang lebih tinggi pada periode IPO untuk memberikan sinyal baik ke pasar sesuai dengan teori persinyalan. Praktik manipulasi laba yang dilakukan oleh perusahaan tentu memiliki dampak negatif terhadap kinerja perusahaan pada periode berikutnya. Penelitian ini menganalisis pengaruh manipulasi laba pada periode IPO terhadap persistensi laba. Hasil dari analisis data menunjukkan bahwa manajemen laba riil tidak berpengaruh negatif terhadap persistensi laba namun justru memberikan pengaruh positif secara signifikan. Hasil penelitian ini juga menunjukkan bahwa manajemen laba akrual berpengaruh negatif terhadap persistensi laba yang menunjukkan bahwa perusahaan yang memanipulasi akrual untuk menyajikan laba yang tinggi kesulitan untuk mempertahankan laba pada periode berikutnya.

Keterbatasan penelitian ini antara lain adalah penulis hanya dapat mengamati dampak dari manajemen laba hanya dalam satu periode setelah IPO karena tahun terakhir yang menjadi observasi adalah tahun 2018. Selain itu, klasifikasi yang digunakan untuk mengestimasi tingkat manajemen laba juga terbatas karena hanya menggunakan klasifikasi per sektor yang dibuat oleh BEI. Penelitian ke depannya dapat melakukan analisis yang lebih jauh terhadap pengaruh yang ditimbulkan oleh praktik manajemen laba. Penelitian ini hanya mencakup dampak yang ditunjukkan pada periode setahun setelah IPO. Penelitian selanjutnya juga dapat menganalisis dampak yang ditimbulkan oleh manajemen laba pada cakupan waktu yang lebih lama dan menggunakan klasifikasi yang lebih spresifik. Selain hanya menggunakan sektor untuk mengestimasi manajemen laba, dapat digunakan klasifikasi sub sektor atau klasifikasi yang lebih akurat mengelompokkan karakteristik dari masing-masing perusahaan yang dapat mempengaruhi hasil penelitian.

\section{REFERENSI}

Alhadab, M. ., Clacher, I., \& Keasey, K. (2015). Real and accrual earnings management and IPO failure risk. Accounting and Business Research, 45(1), 5592.

Alhadab, M. M. (2018). Real and accrual earnings management around initial public offerings in Jordan. International Business Research, 11(1), 2014-2216.

Atwood, T. J., Drake, M. S., \& Myers, L. A. (2010). Book-tax conformity, earnings persistence and the association between earnings and future cash flows. Journal of Accounting and Economics, 50(1), 111-125.

Ball, R., \& Shivakumar, L. (2008). Earnings quality at initial public offerings. Journal of Business Finance and Accounting, 45(2-3), 324-349.

Brau, J. C., \& Fawcett, S. E. (2006). Initial public offerings: An analysis of theory and practice. The Journal of Finance, 61(1), 399-436.

Cohen, D. A., \& Zarowin, P. (2010). Accrual-based and real earnings management 
activities around seasoned equity offerings. Journal of Accounting and Economics, 50(1), 2-19.

Dechow, P., Ge, W., \& Schrand, C. (2010). Understanding earnings quality: A review of the proxies, their determinants and their consequences. Journal of Accounting \& Economics, 50(2-3), 344-401.

Dechow, P. M., Sloan, R. G., \& Sweeney, A. P. (1995). Detecting Earnings Management. The Accounting Review, 70(2), 193-225.

DeFond, M. L. (2010). Earnings quality research: Advances, challenges and future research. Journal of Accounting and Economics, 50(2-3), 402-409.

Ernst and Young. (2019). Global IPO trends: Q3 2019. https://assets.ey.com/content/dam/ey-sites/eycom/en_gl/topics/ipo/ey-quarterly-ipo-trends-2019-q3.pdf

Ertimur, Y., Sletten, E., \& Sunder, J. (2014). Large shareholders and disclosure strategies: Evidence from IPO lockup expirations. Journal of Accounting and Economics, 58(1), 79-95.

Ertimur, Y., Sletten, E., Sunder, J., \& Weber, J. (2018). When and why do IPO firms manage earnings? Review of Accounting Studies, 23(3), 872-906.

Field, L. C., \& Hanka, G. (2001). The expiration of IPO share lockups. Journal of Finance. 56(2), 471-500.

Graham, J. R., Harvey, C. R., \& Rajgopal, S. (2005). The economic implications of corporate financial reporting 3-73. Journal of Accounting E Economics, 40(1-3), 3-73.

Jensen, M. C., \& Meckling, W. H. (1976). Theory of the firm: Managerial behavior, agency cost, and ownership structure. Journal of Financial Economics, 3(4), 305360.

Kedia, S., Rajgopal, S., \& \& Zhou, X. (2017). Large shareholders and credit ratings. Journal of Financial Economics, 124(3), 632-653.

Kothari, S. P., Mizik, N., \& Roychowdhury, S. (2016). Managing for the moment: The role of earnings management via real activities versus accruals in SEO valuation. The Accounting Review, 91(2), 559-586.

$\mathrm{Li}, \mathrm{V}$. (2019). The effect of real earnings management on the persistence and informativeness of earnings. The British Accounting Review, 51(4), 402-423.

Lipe, R. (1990). The relation between stock returns and accounting earnings given alternative formation. Accounting Review, 65(1), 49-71.

Meini, Z., \& Siregar, S. V. (2014). The effect of accrual earnings management and real earnings management on earnings persistence and cost of equity. Journal of Economics, Accountancy Ventura, 17(2), 269-280.

Premti, A. (2013). Earnings management prior to initial public offerings and its effect on firm performance: International evidence. International Journal of Financial Research, 4(3), 10-24.

Rajizadeh, S., \& Rajizadeh, S. (2013). Examining the factors affecting earnigns persistency among the listed firms in Tehran Stock Exchange. European Online Journal of Natural and Social Sciences, 2(3), 2073-2079.

Ritter, J. (1991). The long-run performance of initial public offerings. The Journal of Finance, 46(1), 3-27.

Roychowdhury, S. (2006). Earnings management through real activities manipulation. Journal of Accounting and Economics, 42(3), 335-370. 
Scott, W. R. (2015). Financial Accounting Theory, 7th Edition. Pearson.

Subramanian, A., \& Nilakanta, S. (1996). Organizational innovativeness: Exploring the relationship between organizational determinants of innovation, types of innovations, and measures of organizational performance. Omega, 24(6), 631647.

Teoh, S. H., Welch, I., \& Wong, T. J. (1998). Earnings management and the longrun market performance of initial public offerings. Journal of Finance, 53(6), 1935-1974.

Widyaningtyas, A. P. (2009). Manajemen laba sebelum initial public offering [Universitas Sanata Dharma]. https://repository.usd.ac.id/15780/ 